\title{
KETERKAITAN FAKTOR DEMOGRAFI DENGAN MOTIF BERPINDAH PILIHAN LAYANAN HOTEL BERBINTANG DI KOTA BENGKULU
}

\author{
Sri Wahyu Putri \\ Muhartini Salim \\ Fakultas Ekonomi dan Bisnis Universitas Bengkulu
}

\begin{abstract}
The purpose of this research is to examine the relationship between demographic factors and switch motive based on variabels pricing, inconvenience, core service failure, service encounter failure, response to service failure, attraction by the competitor, ethical problems, and involuntary switching. A questionnaire was utilized on 93 respondents of one-star hotels, 61 respondents of two-stars hotels, and 59 respondents of three-stars hotels in Bengkulu City. Analysis technique used is a test cross tabulation. According to the results of this research, the average responses of respondents to switch motive based on variabels pricing, inconvenience, core service failure, service encounter failure, response to service failure, attraction by competitor, ethical problems, and involuntary switching is in high category. The results of this analysis indicate that the overall demographic factors have a significant relationship with the switch motive based on variabels pricing, the core service failure, response to service failure, and ethical problems. However, overall demographic factors exist which hasn't relationship with the switch motive based on variabels inconvenience, service encounter failure, attraction by competitor and involuntary switching.
\end{abstract}

Keywords: Demographic, Pricing, Inconvenience, Core Service Failure, Involuntary Switching.

\section{PENDAHULUAN}

\section{Latar Belakang}

Keberhasilan industri pariwisata di Bengkulu sangat dipengaruhi oleh berbagai faktor, salah satu faktor tersebut adalah dengan adanya keberadaan hotel yang menjadi sarana beristirahat para pengunjung baik yang berasal dari dalam Bengkulu, nasional, maupun mancanegara. Bisnis jasa di bidang perhotelan merupakan bisnis yang selalu mengalami fluktuasi, terbukti dari tinggi rendahnya tingkat hunian kamar hotel berbintang yang ada di Bengkulu, baik hotel berbintang 1, hotel berbintang 2 maupun hotel berbintang 3 untuk setiap tahun. Berikut ini adalah jumlah tingkat hunian kamar hotel berbintang dari bulan Oktober 2015 sampai bulan Oktober 2016. 
Tabel 1.1

Tingkat Penghunian Kamar Pada Hotel Berbintang Di Provinsi Bengkulu Bulan Oktober 2015-Oktober 2016

\begin{tabular}{|c|c|c|c|c|}
\hline \multirow[t]{2}{*}{ Bulan } & \multicolumn{3}{|c|}{$\begin{array}{l}\text { Klasifikasi Hotel Dan Tingkat } \\
\text { Penghunian Kamar (\%) }\end{array}$} & \multirow{2}{*}{$\begin{array}{l}\text { Rata- } \\
\text { rata } \\
\text { Bintang }\end{array}$} \\
\hline & $\begin{array}{l}\text { Berbintang } \\
1\end{array}$ & $\begin{array}{l}\text { Berbintang } \\
2\end{array}$ & $\begin{array}{l}\text { Berbintang } \\
3\end{array}$ & \\
\hline Oktober'15 & 89,78 & 64,23 & 40,59 & 55,76 \\
\hline November'15 & 62,57 & 63,63 & 52,41 & 56,75 \\
\hline Desember'15 & 54,37 & 77,13 & 35,54 & 47,47 \\
\hline Januari'16 & 58,78 & 44,79 & 58,01 & 55,68 \\
\hline Februari'16 & 55,47 & 35,59 & 68,80 & 59,68 \\
\hline Maret'16 & 71,43 & 75,46 & 63,18 & 68,69 \\
\hline April'16 & 52,74 & 67,63 & 53,65 & 57,95 \\
\hline Mei'16 & 54,12 & 70,95 & 59,69 & 62,30 \\
\hline Juni'16 & 30,26 & 75,45 & 34,60 & 48,65 \\
\hline Juli'16 & 58,28 & 72,11 & 44,61 & 56,00 \\
\hline Agustus'16 & 59,64 & 82,30 & 44,07 & 59,28 \\
\hline September'16 & 60,26 & 51,97 & 60,09 & 58,00 \\
\hline Oktober'16 & 43,80 & 70,09 & 44,47 & 52,62 \\
\hline
\end{tabular}

Sumber : Bengkulu.Bps.go.id/tanggal akses 22/12/2016

Berdasarkan Tabel 1.1 dari hasil klasifikasi yang dilakukan Badan Pusat Statistika Provinsi Bengkulu pada tahun 2015-2016 mengindikasikan bahwa dengan adanya persentase tingkat hunian kamar hotel berbintang tersebut dapat memicu terjadinya persaingan yang ketat pada bisnis jasa perhotelan. Terbukti belakangan ini terus bermunculan hotel-hotel baru khususnya hotel berbintang. Kondisi dimana adanya peningkatan jumlah hotel-hotel baru khususnya hotel berbintang di Kota Bengkulu mengakibatkan hotel-hotel yang lama harus mampu bersaing dengan ketatnya bahkan sering terjadi persaingan yang tidak sehat. Dengan adanya persaingan yang ketat dan tidak sehat tersebut, maka Darpito (2008) mengatakan bahwa tantangan persaingan dalam jasa hotel merupakan permasalahan yang harus dipecahkan.

Keadaan ini tentu dapat mengakibatkan konsumen untuk memilih hotel mana yang dianggap mampu memenuhi keinginan mereka serta memiliki pengalaman yang menyenangkan dalam proses pemakaian jasa tersebut. Namun apabila hotel tersebut dianggap belum mampu memuaskan pelanggannya ketika menggunakan jasa tersebut, maka konsumen akan segera berpaling ke hotel berbintang lainnya yang menurut mereka dapat memberikan pelayanan yang lebih baik. Keengganan 
menggunakan layanan pada perusahaan jasa yang mengakibatkan terjadinya motif berpindah yang dilakukan oleh konsumen dari jasa sebelumnya ke jasa yang lain. Untuk mengatasi agar motif berpindah yang dilakukan konsumen pada layanan jasa yang lain, maka perusahaan juga harus mengetahui apa saja yang menjadi motif berpindah yang akan dilakukan oleh konsumen.

Keanevey (1995) mengatakan ada 8 motif yang dilakukan konsumen dalam berpindah ke jasa yang lain yaitu harga, ketidaknyamanan, kegagalan jasa inti, kegagalan interaksi jasa, respon kegagalan jasa, daya tarik saing, masalah etika, dan ketidaksengajaan. Selain 8 motif yang dilakukan konsumen dalam berpindah ke jasa yang lain, tentu saja penyedia jasa perlu mengetahui apakah ada keterkaitan faktor demografi dengan motif bepindah tersebut. Mempelajari tingkah laku konsumen tentunya bukan hal yang mudah, karena konsumen adalah manusia yang setiap individunya mempunyai perbedaan tingkah laku, hal tersebut juga berlaku didalam motif berpindah. Konsumen yang mempunyai latar belakang demografi yang berbeda-beda, akan berdampak dalam memilih suatu jasa yang mereka kehendaki. Maka dari itu, pihak penyedia jasa hotel berbintang harus dapat mengidentifikasi dan memahami keinginan serta kebutuhan para konsumen dengan berbagai macam karakteristiknya dalam memberikan tanggapan terhadap motif berpindah, agar lebih memberikan keuntungan besar melebihi pesaing-pesaingnya dan mempunyai konsumen yang banyak.

\section{TINJAUAN PUSTAKA}

\section{Motif Berpindah}

Motif merupakan suatu kekuatan yang sifatnya internal mengarahkan tingkah laku seseorang untuk melakukan kegiatan tertentu yang tujuannya adalah memuaskan kebutuhan. Tingkat kepuasan dan kegunaan dari sebuah jasa memiliki andil yang cukup besar jika dikaitkan dengan motif berpindah dalam menggunakan jasa. Perilaku konsumen yang tidak puas atau kecewa akan mengakibatkan timbulnya persepsi negatif atas kualitas layanan yang diterima sehingga motif berpindah ke layanan yang lain cukup besar. Perilaku berpindah dapat dinyatakan sebagai proses yang setia pada satu layanan dan akhirnya beralih ke layanan lain, karena ketidakpuasan atau masalah lain (Yani et al., 2014). Oleh karena itu, motif berpindah merupakan fenomena yang sangat penting yang akan dipertimbangkan oleh perusahaan (Listyarini et. al., 2007).

Bansal et. al., (2005) mengatakan niat berpindah adalah tingkat kemungkinan atau kepastian bahwa pelanggaan akan berpindah dari penyedia jasa saat ini ke penyedia jasa yang baru. Niat berpindah dalam konteks layanan merujuk pada kemungkinan 
berubah layanan saat ini ke layanan yang lain (Thaichon dan Quach, 2016). Shen et al., (2006) dan Saleki et al., (2014) menjelaskan maksud niat berpindah sebagai fakta bahwa konsumen lebih memilih atau produk yang lain. Jabeen et al., (2015) mengatakan bahwa niat berpindah adalah sebagai sinyal pemutusan hubungan pelanggan dengan penyedia layanan saat ini sebagian atau sepenuhnya. Niat berpindah adalah keadaan yang muncul setelah kinerja tersebut berkurang dari harapan (Khan et al., 2014). Stewart (1994) mengatakan perilaku beralih ke perusahaan lain dipahami juga sebagai defection atau customer exit. Hal ini juga diartikan sebagai keputusan yang dibuat konsumen untuk melakukan pemberhentian pembelian jasa perusahaan, baik sebagian atau secara keseluruhan (Bolton dan Bronkhurst, 1995; Boote, 1998).

Ketika memeriksa perilaku perpindahan pelanggan secara lebih rinci, ada sejumlah periset berpendapat bahwa sikap pelanggan adalah penentu utama niat mereka untuk berpindah dalam menggunakan jasa (Bansal dan Taylor, 1999). Literatur loyalitas mengklasifikasikan faktor penentu perilaku berpindah pelanggan ke dalam dua kelompok baik dari sisi ekonomi atau kognitif dan social atau afektif (Bolton et al., 2004). Studi tentang beralihnya literatur perilaku menunjukkan tiga kecenderungan utama, pertama-tama mempelajari fitur yang memperkuat hubungan, yaitu mencegah peralihan, yang kedua adalah dampak dari biaya berpindah terhadap retensi dan kepuasan, identifikasi ketiga motif beralih (White dan Yanamandram, 2007). Motif perpindahan pelanggan dari penyedia jasa saat ini ke penyedia jasa yang baru merupakan permasalahan serius yang harus mendapatkan perhatian daru pelaku bisnis. Jika dikaitkan dengan teori perpindahan menurut Keanevey (1995), maka terdapat 8 motif berpindah konsumen dalam menggunakan jasa yaitu harga, ketidaknyamanan, kegagalan jasa inti, kegagalan interaksi jasa, respon kegagalan jasa, daya tarik saing, masalah etika, dan ketidaksengajaan.

\section{Harga}

Penentuan harga suatu produk atau jasa merupakan faktor penting bagi perusahaan untuk mempertahankan pelanggannya agar terus menggunakan produk atau jasa tersebut. Rizwan et. al., (2013) mengatakan bahwa harga adalah peran utama dalam niat beralih pelanggan baik itu produk maupun jasa. Harga yang ditetapkan harus sesuai dengan perekonomian konsumen, agar konsumen dapat membeli barang dan jasa itu. Selain untuk mendapatkan laba, Huwea (2014) juga mengatakan bahwa harga memegang peranan penting dalam pemasaran baik itu bagi penjual maupun pembeli, dan harga merupakan satu-satunya bauran pemasaran yang sering kali dijadikan sebagai bahan pertimbangan bagi konsumen dalam melakukan pembelian. Kumar (2014) mengatakan faktor harga termasuk perilaku berpindah yang melibatkan harga, biaya tambahan, biaya layanan, harga penawaran, kupon, dan 
harga promosi. Caroline dan Kuswoyo (2013) mengatakan harga merupakan faktor ekstrinsik sebagai fungsi pengganti kualitas ketika pelanggan tidak memiliki informasi yang cukup mengenai atribut intrinsik sehingga pelanggan menggunakan harga untuk menduga kualitas ketika hanya hargalah yang diketahui. Sopiah dan Syihabudhin (2008:144) mengatakan ada tiga jenis dalam penetapan harga yaitu penetapan harga rendah, harga biasa, dan harga tinggi. Harga yang rendah dianggap sebagai pertanda bahwa kualitasnya rendah. Sebaliknya harga tinggi mencerminkan kualitas tinggi.

\section{Ketidaknyamanan}

Perpindahan pelanggan ke jasa yang lain bisa terjadi apabila pelanggan merasakan ketidaknyaman ketika menggunakan jasa yang ditawarkan. Hal ini bisa terjadi karena lokasi penyedia produk atau jasa yang tidak mudah dijangkau, kenyamanan ruang, dan waktu menunggu untuk dilayani (Keaveney, 1995). Bansal (2005) menemukan bahwa lebih dari seperempat responden telah beralih karena ketidaknyamanan. Begitu juga dengan pendapat Sidhu (2005) yang mengatakan bahwa ketidaknyamanan adalah faktor terpenting ke dua untuk perilaku peralihan layanan mobile, seperti waktu tunggu layanan pelanggan yang menjadi isu penting di pasar Yordania. Ketidaknyamanan adalah kejadian yang mengganggu atau mempersulit pelanggan. Dalam mengkonsumsi produk, ketidaknyamanan menimbulkn efek negatif pada sikap pelanggan dan tingkat kepuasan pelanggan (Ninh, 2010 dalam Irianto et al., 2015; Olsen, 2007). Sementara itu, dalam konteks niat untuk beralih, ketidaknyamanan mengacu pada semua masalah yang membuat konsumen merasa bersalah atau membuat keputusan beralih (Grace dan O'Cass, 2001). Ketidaknyamanan tentu saja berkaitan dengan kenyamanan. Hal ini dijelaskan dalam penelitian yang dilakukan oleh Oborne (1995) untuk pertama kalinya mendefinisikan istilah kenyamanan sebagai the absence of discomfort atau tidak adanya ketidaknyamanan.

\section{Kegagalan Jasa Inti}

Kegagalan jasa inti merupakan penyebab kepindahan konsumen karena kesalahan ataupun masalah teknis pada jasa yang ditawarkan kepada konsumen (Keaveney, 1995). Sehingga apabila terjadi kesalahan dalam memberikan layanan tersebut, sangat penting bagi penyedia jasa untuk cepat memperbaiki kegagalan yang terjadi tersebut karena kegagalan tersebut langsung dirasakan oleh pelanggannya. Kegagalan jasa inti adalah kesalahan yang diciptakan oleh penyedia layanan, seperti produk dan fasilitas yang buruk (Syratemeyer et al., 2014). Gronroos (2007) menggambarkan jasa inti sebagai alasan bagi perusahaan yang berada di pasar dan memecahkan layanan tambahan sekitarnya menjadi dua kelompok yaitu memungkinkan atau memfasilitasi layanan dan meningkatkan atau mendukung layanan. Kegagalan jasa didefinisikan sebagai kinerja jasa yang tidak dapat 
memenuhi harapan pelanggan (Hoffman dan Bateson, 1997). Lovelock dan Wright (2005:144) mengatakan kegagalan jasa inti adalah persepsi pelanggan bahwa satu aspek terte ntu atau lebih dalam penyerahan jasa tidak memenuhi harapan mereka. Gagalnya perusahaan dalam memberikan produk atau pelayanan akan memicu pada niat berpindah.

\section{Kegagalan Interaksi Jasa}

Kegagalan interaksi jasa merupakan berpindahnya konsumen disebabkan oleh kegagalan pelayanan jasa seperti perilaku karyawan yang tidak peduli, tidak sopan, tidak tanggap, dan tidak memiliki pengetahuan yang terkait dengan produk/jasa perusahaan (Keaveney, 1995). Apabila konsumen dilayani oleh karyawan yang tidak dapat memberikan solusi atas permasalahan yang dihadapi, maka konsumen akan terus mencari jawaban atas permasalahannya hingga ke penyedia jasa lain. Bila penyedia jasa lain dapat memberikan solusi tersebut, maka besar kemungkinan konsumen akan memindahkan kepercayaannya kepada penyedia jasa tersebut.

Liang et al., (2013) mengatakan kegagalan interaksi jasa dalam kategori ini berkaitan dengan kualitas interaksi antara pelanggan dan karyawan perusahaan jasa, yang secara langsung berhubungan dengan penyedia layanan telepon seluler dan juga perusahaan jasa lainnya. Kegagalan interaksi jasa dianggap sebagai alasan kedua yang paling penting untuk beralih konsumen di industri jasa. Kegagalan ini terkait dengan manusia, faktor dalam perusahaan karyawan yang memperlakukan konsumen dengan cara yang tidak sopan, tidak peduli, tidak responsif dapat menyebabkan ketidakpuasan di antara konsumen, dan seorang karyawan yang tidak kompeten. Kegagalan interaksi jasa membutuhkan pendekatan dimensional untuk mengukur kualitas interaksi dari sebuah pertemuan layanan (Chandon et al., 1997). Cara untuk mengukur kualitas interaksi tersebut, dapat dilakukan dari dua sisi, yakni dari pihak pelanggan dan pihak perusahaan, terutama dalam bidang industri jasa. Sehingga, interaksi menjadi suatu hal yang penting, karena dengan adanya pertemuan secara langsung dari penyedia jasa memungkinkan pelanggan merasakan sebuah pengalaman yang membuatnya melakukan suatu tindakan yaitu tindakan positif pelanggan seperti rasa senang yang mengakibatkan komunikasi WOM dapat terjadi. Zeithaml et al., (2009) juga mengemukakan bahwa interaksi jasa (service encounter) didefinisikan sebagai titik pertemuan antara konsumen dengan penyedia jasa dimana terjadi interaksi antara kedua pihak tersebut.

\section{Respon Kegagalan Jasa}

Respon kegagalan jasa merupakan terjadinya perpindahan konsumen karena kegagalan perusahaan penyedia jasa dalam menangani keluhan konsumen (Keaveney, 1995). Zeithaml et al., (1990) mendefinisikan responsif sebagai kepentingan yang ditunjukkan dalam memberikan layanan yang cepat kepada 
pelanggan bila diperlukan. Pelanggan merasa puas saat bank memberikan perhatian individual dan karyawan memperhatikan masalah yang dialami pelanggan terkait keamanan dalam transaksi (Kumar et al., 2009).

Respon kegagalan jasa termasuk masalah yang timbul saat menangani kegagalan layanan, situasi konflik, menanggapi keluhan (melibatkan respons negatif, tidak ada tanggapan atau tanggapan paksa) (Zikiene dan Bakanauskas, 2009). Respon kegagalan pelanggan tentu berkaitan dengan perilaku komplain yang tidak menyebabkan kepuasan. Hal ini tentu saja tergantung pada bagaimana komplain diterima dan diperlakukan perusahaan sebagai sesuatu yang dapat meningkatkan kepuasan. Efek negatif dari komplain adalah terjadinya word of mouth negative yang dapat membahayakan reputasi dan merek perusahaan. Jadi, ada hubungan antara citra negatif dan komplain terhadap kepercayaan merek dan loyalitas konsumen. Semakin sedikit complain pelanggan, maka akan meningkatkan loyalitas pelanggan (Tax et al., 1998).

\section{Daya Tarik Saing}

Sulistiyani (2006) mengatakan daya tarik pesaing adalah konsumen mengatakan bahwa lebih baik berpindah ke layanan produk yang lebih baik daripada menerima layanan dari penyedia produk yang tidak memuaskan. Konsumen berpindah ke layanan produk yang lebih baik, lebih dapat dipercaya, atau menyediakan kualitas yang lebih tinggi. Banyak konsumen berpindah ke layanan lebih baik meskipun penyedia layanan yang lebih mahal. Daya tarik saing merupakan perpindahan konsumen karena kemenarikan perusahaan lain dibandingkan dengan perusahaan sebelumnya yang menyebabkan ketidakpuasan (Keaveney, 1995). Srinivasan (1996) mengatakan situasi persaingan tinggi menyebabkan kecenderungan konsumen berpindah tinggi, sedangkan situasi persaingan yang rendah menyebabkan kecenderungan konsumen berpindah juga rendah.

Salah satu model keunggulan daya saing perusahaan yang berkelanjutan yang mengkombinasikan elemen sumber daya unik dan kompetensi perusahaan untuk membangun daya saing adalah resource-based view. Barney (1991) mengatakan bahwa resource-based view menyatakan bahwa untuk meraih daya saing dan keuntungan yang berkelanjutan maka perusahaan harus berusaha mencari dan menumbuhkan kapabilitas khusus dari semua sumber daya yang dimiliki. Dalam beralih pelanggan diprediksi, keberadaan objek wisata alternatif variabel sangat penting (Zang et al., 2012).

\section{Masalah Etika}

Masalah etika merupakan masalah yang berhubungan dengan moral, ketidakamanan, ketidaksehatan, ataupun masalah perilaku yang berhubungan dengan nilai-nilai sosial (Keaveney, 1995). Masalah etika dalam kategori ini adalah 
perilaku tidak jujur yang ditunjukan oleh para karyawan kepada para pelanggan, kemudian rasa tidak aman juga dapat dirasakan oleh konsumen karena identitas yang seharusnya menjadi rahasia disampaikan kepada pihak lain tanpa persetujuannya. Liang et al., (2013) mengatakan kategori ini mencakup perilaku tidak etis, ilegal, atau perilaku lainnya dari penyedia layanan yang menyimpang dari norma sosial atau menimbulkan gangguan psikologis pada pelanggan untuk mendapatkan kepatuhan pelanggan, misalnya penyedia layanan mungkin terusmenerus menelepon atau mengirim pesan teks untuk mengingatkan pelanggan agar membayar tagihan atau penyedia layanan mengenakan biaya tinggi untuk sementara menghentikan layanan.

Dalimunthe (2004) menjelaskan bahwa dalam menghindari terjadinya masalah etika dalam bisnis, ada beberapa hal yang perlu di perhatikan, yaitu:

1. Pengendalian diri

Pengendalian diri berarti para pelaku bisnis dan pihak yang terkait mampu mengendalikan diri mereka masing-masing untuk tidak memperoleh apapun dari siapapun dan dalam bentuk apapun.

2. Pengembangan tanggung jawab sosial (Social Responsibility)

Pelaku bisnis dituntut untuk peduli dengan keadaan masyarakat, bukan hanya dalam bentuk uang dengan jalan memberikan sumbangan, akan tetapi melakukan hal yang lebih kompleks lagi, dapat dicontohkan bahwa kesempatan yang dimiliki oleh pelaku bisnis untuk menjual pada tingkat harga yang tinggi sewaktu terjadinya excess demand harus menjadi perhatian dan kepedulian bagi pelaku bisnis dengan tidak memanfaatkan kesempatan ini untuk mengambil keuntungan yang berlipat ganda.

3. Menciptakan persaingan yang sehat

Persaingan dalam dunia bisnis perlu untuk meningkatkan efisiensi dan kualitas, tetapi persaingan tersebut tidak mematikan yang lemah, dan sebaliknya, harus terdapat jalinan yang erat antara pelaku bisnis besar dengan pelaku bisnis dari golongan menengah kebawah, sehingga dengan perkembangannya perusahaan besar mampu memberikan spread effect terhadap perkembangan sekitarnya.

4. Menerapkan konsep "pembangunan berkelanjutan"

Dunia bisnis seharusnya tidak memikirkan keuntungan hanya pada saat sekarang, tetapi perlu memikirkan bagaimana dengan keadaan dimasa mendatang. Berdasarkan hal tersebut, jelas pelaku bisnis dituntut tidak mengekspoitasi lingkungan dan keadaan saat sekarang semaksimal mungkin tan pa mempertimbangkan lingkungan dan keadaan dimasa datang walaupun saat sekarang merupakan kesempatan untuk memperoleh keuntungan besar.

5. Konsekuen dan konsisten dengan aturan-aturan yang telah disepakati bersama Semua masalah etika dalam bisnis akan terjadi apabila setiap orang tidak bisa konsekuen dan konsisten dengan etika tersebut. Seandainya semua etika bisnis telah disepakati, sementara ada oknum, baik pengusaha sendiri maupun pihak 
yang lain mencoba untuk melakukan kecurangan demi kepentingan pribadi, jelas semua konsep etika bisnis itu akan mati satu per satu.

\section{Ketidaksengajaan}

Salah satu faktor yang memengaruhi keputusan untuk tinggal atau beralih ke layanan lain adalah perpindahan tidak disengaja (Kiser, 2002). Perpindahan tidak disengaja didefinisikan sebagai keengganan pelanggan untuk beralih ke bank, namun hal itu mungkin disebabkan karena faktor yang tidak dapat dihindari seperti peralihan tempat tinggal, penutupan bisnis oleh penyedia layanan, dan lain-lain. (East et al., 2001).

Ketidaksengajaan terjadi karena faktor di luar kemampuan konsumen maupun perusahaan penyedia jasa, seperti pindahnya tempat perusahaan penyedia jasa, ataupun pindahnya tempat tinggal konsumen (Keaveney, 1995). Hal ini termasuk berpindah, karena penyedia layanan jasanya berpindah, atau sudah tidak tersedia lagi. Konsumen yang secara bebas memilih untuk berpindah antar penyedia jasa dinamakan voluntary migrant. Sedangkan konsumen yang tidak memiliki pilihan selain pindah penyedia jasa, seperti penyedia jasa saat ini telah tutup atau bangkrut merupakan refugees, misalnya berpindahnya lokasi rumah makan favorit konsumen yang tidak mudah dijangkaunya, sehingga konsumen memutuskan untuk pindah ke rumah makan yang lebih dekat dengan tempat tinggal atau tempatnya bekerja (Bansal et. al., 2005). Perilaku berpaling tidak hanya disebabkan oleh keputusan yang berbeda, tetapi juga oleh faktor tak disengaja yang tidak terkait dengan keputusan yang berbeda (Roos, 1999).

\section{METODE PENELITIAN}

Jenis penelitian ini adalah jenis penelitian deskriptif kualitatif. Sampel penelitian ini adalah 93 responden hotel bintang 1, 61 responden hotel bintang 2, dan 59 responden hotel bintang 3 di Kota Bengkulu dengan pengambilan sampel melalui accidental sampling. Jenis data yang digunakan adalah data primer berupa kuesioner offline dan online sebanyak 250 kuesioner. Metode pengumpulan data yang dilakukan dalam penelitian ini menggunakan kuesioner offline dan online. Metode analisis yang digunakan dalam penelitian ini adalah metode analisis deskriptif dengan uji crosstabulation.

\section{HASIL DAN PEMBAHASAN}

Berdasarkan hasil pengolahan data menggunakan crosstabulation pada penelitian ini menunjukkan bahwa faktor demografi baik dari segi jenis kelamin, umur, 
pekerjaan, pendapatan, jenis hotel dan frekuensi menginap ternyata memiliki keterkaitan yang tinggi dengan motif berpindah berdasarkan variabel harga. Keterkaitan yang tinggi antara faktor demografi dengan motif berpindah berdasarkan variabel harga adalah sebagian konsumen yang mencurigai atau mendapati kejanggalan seperti tarif yang terlalu tinggi yang tidak sesuai dengan fasilitas maupun pelayanan, yang memang ada hal-hal yang tidak dikemukakan secara gamblang oleh pihak hotel kepada para konsumennya. Saat konsumen memesan kamar hotel, yang pertama ditawarkan adalah kamar-kamar dengan tarif tinggi permalamnya dan tarif hotel yang dipesan secara online dapat meningkat $30 \%$. Tapi sebenarnya masih bisa diturunkan maksimal 20\% supaya kedua belah pihak sama-sama diuntungkan. Dengan adanya keterkaitan yang tinggi antara faktor demografi dengan motif berdasarkan harga, maka yang harus dilakukan oleh pihak hotel agar tidak kehilangan para konsumennya yaitu pihak penyedia jasa hotel berbintang di Kota Bengkulu harus tetap memerhatikan dalam penetapan harga, baik itu tarif kamar yang mahal, perbedaan harga yang ditetapkan tidak sesuai dengan yang diiklankan, maupun harga yang tidak sesuai dengan pelayanan. Faktor demografi baik dari segi jenis kelamin, pekerjaan, pendapatan, jenis hotel dan frekuensi menginap ternyata memiliki keterkaitan yang tinggi dengan motif berpindah berdasarkan variabel ketidaknyamanan.

Keterkaitan yang tinggi antara faktor demografi (jenis kelamin, pekerjaan, pendapatan, jenis hotel dan frekuensi menginap) dengan motif berpindah berdasarkan variabel ketidaknyamanan disebabkan karena sebagian konsumen sangat memperhatikan kenyamanan. Jika dilihat dari faktor demografi berdasarkan umur, hasilnya tidak ada keterkaitan dengan motif berpindah berdasarkan variabel ketidaknyamanan. Sehingga dapat disimpulkan bahwa faktor demografi secara keseluruhan tidak memiliki keterkaitan dengan motif berpindah berdasarkan variabel ketidaknyamanan. Faktor demografi baik dari segi jenis kelamin, umur, pekerjaan, pendapatan, jenis hotel dan frekuensi menginap ternyata memiliki keterkaitan yang tinggi dengan motif berpindah berdasarkan variabel kegagalan jasa inti. Keterkaitan yang tinggi antara faktor demografi dengan motif berpindah berdasarkan kegagalan jasa inti adalah karyawan hotel sebelumnya telah melakukan kesalahan dalam pencatatan harga yang tidak sesuai dengan yang ditawarkan sebelumnya, karyawan hotel sebelumnya tidak dapat memberikan informasi tentang hotel dengan jelas, maupun pelayanan yang diberikan oleh karyawan pada hotel sebelumnya tidak dapat diandalkan. Faktor demografi baik dari segi jenis kelamin, pendapatan, jenis hotel dan frekuensi menginap ternyata memiliki keterkaitan yang tinggi dengan motif berpindah berdasarkan variabel kegagalan interaksi jasa. Jika dilihat dari faktor demografi berdasarkan umur dan pekerjaan konsumen, hasilnya tidak ada keterkaitan dengan motif berpindah berdasarkan variabel kegagalan interaksi jasa. Sehingga dapat disimpulkan bahwa 
faktor demografi secara keseluruhan tidak memiliki keterkaitan dengan motif berpindah berdasarkan variabel kegagalan interaksi jasa. Berdasarkan hasil pengolahan data menggunakan crosstabulation pada penelitian ini menunjukkan bahwa faktor demografi baik dari segi jenis kelamin, umur, pekerjaan, pendapatan, jenis hotel dan frekuensi menginap ternyata memiliki keterkaitan yang tinggi dengan motif berpindah berdasarkan variabel respon kegagalan jasa. Faktor demografi baik dari segi umur, pekerjaan, jenis hotel dan frekuensi menginap ternyata memiliki keterkaitan yang tinggi dengan motif berpindah variabel daya tarik saing.

Jika dilihat dari faktor demografi berdasarkan jenis kelamin dan pendapatan konsumen, hasilnya tidak ada keterkaitan dengan motif berpindah berdasarkan variabel daya tarik saing. Sehingga dapat disimpulkan bahwa faktor demografi secara keseluruhan tidak memiliki keterkaitan dengan motif berpindah berdasarkan variabel daya tarik saing. faktor demografi baik dari segi jenis kelamin, umur, pekerjaan, pendapatan, jenis hotel dan frekuensi menginap ternyata memiliki keterkaitan yang tinggi dengan motif berpindah berdasarkan variabel masalah etika. Keterkaitan yang tinggi antara faktor demografi dengan motif berpindah berdasarkan masalah etika menunjukan bahwa selama menginap pada hotel tertentu, para konsumen hotel tidak merasakan adanya keamanan dan perlakuan yang baik dari karyawan hotel tersebut. Maka dari itu, masalah etika pada perusahaan jasa tetap harus diperhatikan agar mampu menunjukan perusahaan tersebut memiliki kemampuan dalam memberikan pelayanan yang dapat diandalkan bagi para pelanggan agar tidak berpindah dan dalam memberikan janjijanji kepada pelanggan seperti memberikan jaminan keamanan barang-barang milik pelanggan lebih ditepati lagi agar mampu menumbuhkan sikap kepercayaan pelanggan terhadap perusahaan tersebut. Berdasarkan hasil pengolahan data menggunakan crosstabulation pada penelitian ini menunjukkan bahwa faktor demografi baik dari segi pekerjaan, jenis hotel dan frekuensi menginap ternyata memiliki keterkaitan yang tinggi dengan motif berpindah berdasarkan variabel ketidaksengajaan. Jika dilihat dari faktor demografi berdasarkan jenis kelamin, umur, dan pendapatan, hasilnya tidak ada keterkaitan dengan motif berpindah berdasarkan variabel ketidaksengajaan. Tidak ada keterkaitan antara faktor demografi (kelamin, umur, dan pendapatan) dengan motif berpindah berdasarkan ketidaksengajaan, berarti sebagian konsumen mengganggap bahwa ketidaksengajaan yang terjadi atas diluar kendali konsumen maupun karyawan hotel tidak terlalu sering terjadi, sehingga ketidaksengajaan bukan menjadi alasan bagi konsumen dalam memiliki motif berpindah pilihan layanan hotel berbintang yang lain. Sehingga dapat disimpulkan bahwa faktor demografi secara keseluruhan tidak memiliki keterkaitan dengan motif berpindah berdasarkan variabel ketidaksengajaan. 


\section{SIMPULAN}

Berdasarkan hasil penelitian serta pembahasan tentang keterkaitan faktor demografi dengan motif berpindah pilihan layanan hotel berbintang di Kota Bengkulu, maka dapat disimpulkan sebagai berikut:

1. Hasil rata-rata tanggapan responden terhadap motif berpindah berdasarkan variabel harga, ketidaknyamanan, kegagalan jasa inti, kegagalan interaksi jasa, respon kegagalan jasa, daya tarik saing, masalah etika, ketidaksengajaan berada pada klasifikasi tinggi.

2. Hasil temuan penelitian menunjukan bahwa faktor demografi secara keseluruhan baik dari segi jenis kelamin, umur, pekerjaan, pendapatan, jenis hotel, dan frekuensi menginap memiliki keterkaitan yang tinggi dengan motif berpindah berdasarkan variabel harga. Hal ini berarti semakin banyak konsumen yang mempermasalahkan harga hotel yang ditawarkan baik dari segi harga yang mahal, harga tidak sesuai dengan pelayanan, maupun harga tidak sesuai antara yang ditawarkan dengan yang diiklankan, maka kemungkinan motif berpindah berdasarkan harga sangat besar.

3. Hasil temuan penelitian menunjukan bahwa faktor demografi dari segi jenis kelamin, pekerjaan, pendapatan, jenis hotel, dan frekuensi menginap memiliki keterkaitan yang tinggi dengan motif berpindah berdasarkan variabel ketidaknyamanan. Sedangkan faktor demografi dari segi umur, ternyata tidak memiliki keterkaitan dengan motif berpindah berdasarkan variabel ketidaknyamanan. Hal ini berarti konsumen yang memiliki faktor demografi dari segi jenis kelamin, pekerjaan, pendapatan, jenis hotel, dan frekuensi menginap telah merasakan adanya ketidaknyamanan saat menginap pada hotel sebelumnya. Sedangkan konsumen yang memiliki faktor demografi dari segi umur menyatakan bahwa ketidaknyamanan bukan menjadi motif mereka dalam berpindah pilihan layanan hotel yang lain. Sehingga dapat disimpulkan bahwa faktor demografi secara keseluruhan tidak memiliki keterkaitan dengan motif berpindah berdasarkan variabel ketidaknyamanan.

4. Hasil temuan penelitian menunjukan bahwa faktor demografi secara keseluruhan baik dari segi jenis kelamin, umur, pekerjaan, pendapatan, jenis hotel, dan frekuensi menginap memiliki keterkaitan yang tinggi dengan motif berpindah berdasarkan variabel kegagalan jasa inti. Hal ini berarti meskipun konsumen memiliki latar belakang faktor demografi yang berbeda, tetapi kegagalan jasa inti yang dirasakan oleh konsumen tersebut sebagai motif berpindah pilihan layanan hotel setelah konsumen merasakan pada hotel sebelumnya tidak dapat mengatasi kegagalan jasa inti dengan baik. 
5. Hasil temuan penelitian menunjukan bahwa faktor demografi dari segi jenis kelamin, pendapatan, jenis hotel, dan frekuensi menginap memiliki keterkaitan yang tinggi dengan motif berpindah berdasarkan variabel kegagalan interaksi jasa. Sedangkan faktor demografi dari segi umur dan pekerjaan, ternyata tidak memiliki keterkaitan dengan motif berpindah berdasarkan kegagalan interaksi jasa. Hal ini konsumen yang memiliki faktor demografi dari segi jenis kelamin, pendapatan, jenis hotel, dan frekuensi menginap menganggap bahwa hotel sebelumnya telah terjadi kegagalan interaksi jasa dan belum dapat mengatasi dengan baik. Sehingga, semakin banyak konsumen memiliki faktor demografi dari segi jenis kelamin, pendapatan, jenis hotel, dan frekuensi menginap dan berpendapat hal yang sama tentang permasalahan kegagalan interaksi jasa pada hotel yang sama, maka motif berpindah pilihan layanan hotel berbintang lainnya akan semakin besar. Sedangkan konsumen yang memiliki faktor demografi berdasarkan umur dan pekerjaan dalam penelitian ini menganggap bahwa kegagalan interaksi jasa bukanlah bentuk motif berpindah yang akan mereka lakukan ketika ingin menginap pada hotel yang lain. Sehingga dapat disimpulkan bahwa faktor demografi secara keseluruhan tidak memiliki keterkaitan dengan motif berpindah berdasarkan variabel kegagalan interaksi jasa.

6. Hasil temuan penelitian menunjukan bahwa faktor demografi secara keseluruhan baik dari segi jenis kelamin, umur, pekerjaan, pendapatan, jenis hotel, dan frekuensi menginap memiliki keterkaitan yang tinggi dengan motif berpindah berdasarkan variabel respon kegagalan jasa. Hal ini berarti sebagian pelanggan merasakan kurangnya respon dari karyawan atas kegagalan jasa pada hotel sebelumnya, maka kegagalan respon kegagalan jasa dapat dikatakan sebagai motif pilihan layanan hotel berbintang yang dianggap memiliki respon karyawan yang baik dalam menghadapi permasalahan konsumennya selama menginap pada hotel tertentu.

7. Hasil temuan penelitian menunjukan bahwa faktor demografi dari segi umur, pekerjaan, jenis hotel, dan frekuensi menginap memiliki keterkaitan yang tinggi dengan motif berpindah berdasarkan variabel daya tarik saing. Sedangkan faktor demografi dari segi jenis kelamin dan pendapatan, ternyata tidak memiliki keterkaitan dengan motif berpindah berdasarkan variabel daya tarik saing. Hal ini berarti sebagian konsumen yang memiliki faktor demografi dari segi umur, pekerjaan, jenis hotel, dan frekuensi menginap menganggap bahwa semakin besar daya tarik pesaing yang akan menarik pelanggan untuk menggunakan jasa penginapan hotel berbintang yang lain, maka motif berpindah akan semakin besar. Sedangkan konsumen yang memiliki faktor demografi dari segi jenis 
kelamin dan pendapatan, mengganggap bahwa daya tarik saing yang sangat banyak saat ini tidak dapat menimbulkan motif berpindah pilihan layanan hotel berbintang yang lain, meskipun hotel yang lain menawarkan berbagai penawaran yang cukup menarik perhatian konsumen. Sehingga dapat disimpulkan bahwa faktor demografi secara keseluruhan tidak memiliki keterkaitan dengan motif berpindah berdasarkan variabel daya tarik saing.

8. Hasil temuan penelitian menunjukan bahwa faktor demografi secara keseluruhan baik dari segi jenis kelamin, umur, pekerjaan, pendapatan, jenis hotel, dan frekuensi menginap memiliki keterkaitan yang tinggi dengan motif berpindah berdasarkan variabel masalah etika. Hal ini berarti seluruh konsumen yang menjadi responden penelitian ini mengganggap masalah etika yang buruk pada karyawan hotel sebelumnya telah menimbulkan motif berpindah pilihan layanan hotel berbintang lainnya yang akan dilakukan konsumen ketika ingin menginap lagi pada hotel yang dapat menjaga etika yang baik kepada konsumennya.

9. Hasil temuan penelitian menunjukan bahwa faktor demografi secara dari segi pekerjaan, jenis hotel, dan frekuensi menginap memiliki keterkaitan yang tinggi dengan motif berpindah berdasarkan variabel ketidaksengajaan. Sedangkan faktor demografi dari segi jenis kelamin, umur dan pendapatan, ternyata tidak memiliki keterkaitan dengan motif berpindah berdasarkan variabel ketidaksengajaan. Hal ini berarti meskipun ketidaksengajaan jarang terjadi, tetapi konsumen yang memiliki faktor demografi secara dari segi pekerjaan, jenis hotel, dan frekuensi menginap menganggap bahwa ketidaksengajaan dapat terjadi tanpa diprediksi, karena diluar kendali dari kedua belah pihak baik karyawan maupun konsumen. Sehingga, motif berpindah berdasarkan ketidaksengajaan sangat besar, walaupuun ada juga konsumen yang memiliki faktor demografi dari segi jenis kelamin, umur dan pendapatan mengganggap ketidaksengajaan bukanlah motif berpindah yang akan mereka lakukan dimasa yang akan datang dalam menggunakan jasa hotel selanjutnya. Sehingga dapat disimpulkan bahwa faktor demografi secara keseluruhan tidak memiliki keterkaitan dengan motif berpindah berdasarkan variabel ketidaksengajaan. 


\section{DAFTAR PUSTAKA}

Bansal, H. dan Taylor, S. (1999), The service provider switching model (SPSM), journal of service research, (2)(2), pp 200-218.

Bansal, Harvir, S., Shirley, F., Taylor, dan Yannik St. James. (2005). "Migrating to New Service Providers: Toward a Unifying Framework of Customers Switching Behaviors." Journal of The Academy of Marketing Science, Vol. 33, No.1.

Barney. (1991). "Firm resources and sustained competitive advantage", journal of management, vol 17, no. 1, pp.99-120.

Bolton, Ruth N., dan Tina M. Bronkhorst (1995), "The relationship between customer complaints to the firm and subsequent exit behaviour," in Advances in Consumer Research, Vol. 22, hal.94-100.

Boote, J. (1998). "Towards a comprehensive taxonomy and model of consumer complaining behavior". Journal of Consumer Satisfaction, Dissatisfaction and Complaining Behavior, Vol. 11. pp. 140-151.

Caroline, Olive., dan Kuswoyo., Chandra. (2013). Pengaruh Kualitas Layanan Dan Harga Terhadap Loyalitas Pelanggan Melalui Kepuasan Pelanggan Hotel Zodiak Di Kota Bandung, Jurnal Manajemen, Vol.12, No.2.

Chandon, J-L., Leo, P-Y., dan Philippe, J. (1997), "Service Encounter Dimensions A Dyadic Perspective: Measuring the Dimensions of Service Encounters as Perceived by Customers and Personnel," International Journal of Service Industry Management, 8, 1, pp. 65-86.

Dalimunthe, Ritha F., (2004). Etika Bisnis, e-USU Repository, Universitas Sumatera Utara.

Darpito, Surpiko Hapsoro. (2011). Analisis Switching Behavior Sebagai Upaya Perusahaan Dalam Membangun Keunggulan Kompetitif. Jurnal Manajemen Inovasi dan Bisnis, Vol.1 No.1.

East, R., Lomax, W. dan Narain, R. (2001), "Customer tenure, recommendation and switching", Journal of Consumer Satisfaction, Dissatisfaction and Complaining Behaviour, Vol. 14 No. 1, pp. 46-54.

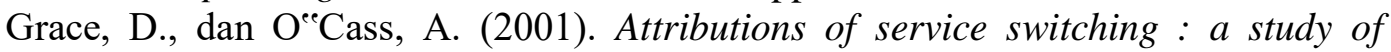
consumers" and providers" perceptions of child-care service deliver, Journal of Servives Marketing, Vol. 15 No. 4, pp. 300 - 321.

Gronroos, C. (2007).Service management and marketing: Customer management in service competition (3rd ed.). Chichester, England: John Wiley \& Sons.

Hoffman, K.D., dan Bateson, J.E.G. (1997)."Essentials of Service Marketing”, Forth Worth, TX: Dryden .

Huwae, Victor E. (2014). Pengaruh Promosi Dan Kebijakan Harga Terhadap Keputusan Menginap Pada Hotel Amaris Di Kota Ambon. Jurnal Ekonomi, Bisnis dan Akuntansi, Vol. 2, No. 3.

Irianto, Heru., Tulus Haryono., Budhi Haryanto., dan Asri Laksmi Riani. (2015). The Model of Consumer's Switching Intention from Conventional Food to Organic Food: An Experimental Design Study, Mediterranean Journal of Social Sciences, No. 6, Vol. 3 
Jabeen, Samrane., Abu Bakar, A.H., dan Saif, U.R. (2015). "Switching Intention : A Case Saudi Arabian Hypermart." International Journal of Economics and Financial Issues, Vol. 5 (Special Issue), pp. 215-222.

Keaveny, Susan M. (1995). "Customer Switching Behavior in Service Industries : An Exploratory Study", Journal of Marketing, Vol. 59 (April), p71-82.

Khan, M.A., Muhammad, R., dan Muhammad S.C. (2014). "Attitude of people towards retention and switching: A study based on Nestle brand in Pakistan." Journal of Public Administration and Governance, ISSN 2161-7104, Vol. 4, No. 2.

Kiser. E.K (2002), Household switching behaviour at depository institutions: Evidence from survery data; Federal Reserve Board, 20th and C ST., NW, Washington, DC 20551, (202) 451-2584.

Kumar., R. Dhakshayani. (2014). "Customer Switching Behaviour In Retail Banking Industry Of India", Journal of Innovative Research and Solution (JIRAS), Vol.1, No.1.

Liang, a Dapeng., Zhenzhong dan Ma b., Liyun Qi c. (2013). Service quality and customer switching behavior in China's mobile phone service sector. Journal of Business Research. 1161-1167.

Listyarini, Ollivia., Jony Oktavian Haryanto., dan Bona Christanto Siahaan, (2009). "The Adoption of Push-Pull and Mooring Model for Small Industry in Indonesia." Jurnal Ekonomi dan Bisnis, Vol. 15, No. 1, 75-88.

Lovelock., Christopher dan Wright.,Lauren K. (2005). Pemasaran Jasa, Terjemahan: Agus Widiantoro, Jakarta, PT. Indeks, Cetakan I.

Oborne, David J. 1995. Ergonomic at Work.Third Edition. England: John Wiley and Sons Ltd.

Olsen, S. O. (2007). Repurchase loyalty: The role of involvement and satisfaction. Psychology \& Marketing, 24(4), 315-341.

Rizwan, Muhammad., Rashid Hidayat., dan Mohsin Ali. (2013). "Antecedents of Customer Switching Intentions: A case study of Nokia Mobile Phones' users." Journal of Public Administration and Governance, Vol. 3, No. 3.

Roos, I. (1999), "Switching processes in customer relationships", Journal of Service Research, Vol. 2 No. 1, pp. 376-393.

Saleki, Reza., Mohsen Saki., dan Mohammad Javad Nekooei. (2014). "A Review on the Effect of Self-congruity Dimensions on Customer's Switching Intention." Journal of Business and Management, Vol. 16, Issue 2, pp. 48-53.

Shen, D., Laffey, J., Lin., Y., dan Huang, X. (2006). Social Influence for Perceived usefulnessand ease-of-use of course delivery system. Journal of Interactive Online Learning. 5(3), 270-282.

Sidhu, A. (2005),"Canadian cellular industry: Consumer Switching Behavior, simonfraser university, unpublished Master`s thesis.

Sopiah dan Syihabudhin. (2008). Manajemen Bisnis Retail. Yogyakarta: CV. Andi Offset.

Srinivasan, M. (1996). New Insight Into Switching Behaviour. Marketing Research: A Magazine of Management and Applications, Vol. 8, No. 1 
Sytratemeyer, Andreas W., Susan D. Geringer., dan Alan Canton. (2014). An Exploratory Investigation of the Effects of Service Failures and Recovery Efforts on Customer Satisfaction. American Journal of Management, 14(3).

Thaichon, Paramaporn dan Quach, Thu Nguyen. (2016). "Integrated Marketing Communications and Their Effects on Customer Switching Intention. "Journal Of Relationship Marketing, Vol. 15, NOS. 1-2, hal. 1-16.Dalimunthe, Ritha F., (2004). Etika Bisnis, e-USU Repository, Universitas Sumatera Utara.

Tax, S.S., Brown, S.W., dan Chandrashekaran, M. (1998). Customer evaluations of experiences: Implications for relationship marketing. Journal of Marketing, 62(2), 60-76.

White, L. and Yanamandram V. (2007). A model of customer retention of dissatisfied business services customers, Managing Service Quality, (17) (3), pp 298-316.

Zang, K.Z.K, Cheung dan Lee. (2012)."Online Service Switching Behavior". Journal of electtonic commerce Research. Vol.13. 184-19.

Zeithaml, V.A; Bitner, M.J dan Gremler, D.D. (2009). Services Marketing : Integrating Customer Focus Across the Firm. 5th Edition; Mc Graw Hill; Boston.

Zikiene K, Bakanauskas AP. (2009). Research of factors influencing loyal customer switching behaviour. Organizacijø Vadyba: Sisteminiai Tyrimai. (52):153. 